\title{
On the age and correlation of the St. Erth Beds, S.W. England, based on planktonic foraminifera
}

\author{
D. GRAHAM JENKINS*, JOHN E. WHITTAKER** \& R. CARLTON* \\ *Department of Earth Sciences, Open University, Milton Keynes \\ **Department of Palaeontology, British Museum (Natural History), London SW7 5BD
}

\begin{abstract}
The paper illustrates and describes 15 species of planktonic foraminifera from the St. Erth Beds, Cornwall, S.W. England. The overlap of the stratigraphic ranges of Globorotalia inflata (d'Orbigny), G. praehirsuta Blow, G. tosaensis Takayanagi \& Saito, Pulleniatina primalis Banner \& Blow, Neogloboquadrina humerosa (Takayanagi \& Saito) and dextrally coiled $N$. pachyderma (Ehrenberg) places the age of the fauna in the Globorotalia inflata Zone, Late Pliocene. The absence of Globorotalia puncticulata (Deshayes), G. truncatulinoides (d'Orbigny) and Neogloboquadrina atlantica (Berggren) confirms this age assignment and with the presence of $G$. inflata (d'Orbigny), the deposition of St. Erth beds can now be accurately placed at between 2.1 and $1.9 \mathrm{Ma}$. For this paper, it has been acceped that the Pliocene-Pleistocene boundary is marked by the first evolutionary appearance of $G$. truncatulinoides at about $1.9 \mathrm{Ma}$.
\end{abstract}

\section{INTRODUCTION}

The dating of the famous sands and clays at St. Erth, Cornwall (Fig. 1), has been a contentious issue since they were first described (Whitley, 1882). In 1982, Jenkins reported rare juvenile specimens of planktonic foraminifera from the clays and predicted that their age was within the Globorotalia inflata Zone, Late Pliocene; this was primarily based on the presence of G. inflata (d'Orbigny) and dextrally coiled Neogloboquadrina pachyderma (Ehrenberg). Up until that time all previous attempts to date the deposits used molluscs or benthic foraminifera (see Mitchell et al., 1973 and Jenkins, 1982, for a review).

After Jenkins' paper was published it was discovered that Millett in a series of short papers (1885-1898) had himself recorded a number of planktonic foraminiferal species from the St. Erth Beds, the material still being preserved in the Heron-Allen and Earland Collection in the British Museum (Natural History), London. A thorough search has yielded the following species, Millett's old names are given in parentheses: Globorotalia inflata (d'Orbigny) (Globigerina inflata in Millett, 1895, 1898), Globigerina bulloides d'Orbigny (in Millett, 1885, 1886), Pulleniatina primalis Banner \& Blow (Pullenia obliquiloculata in Millett, 1898), Globorotalia tosaensis Takayanagi \& Saito (Pulvinulina crassa in Millett, 1898), Globorotalia praehirsuta Blow (Pulvinulina canariensis in Millett, 1898), together with specimens of reworked Cretaceous species (Globigerina cretacea in Millett, 1886).

In 1883, Millett returned from London to live in his native Cornwall, quite near to St. Erth itself, and from there he amassed a very large collection of material from several pits which at that time were being worked for moulding sand and puddling clay. It was at the time too, when the marine fossils, particularly molluscs, from the clays were causing much interest amongst palaeontologists. No doubt it is the size of the total material he must have examined which has resulted in the number of planktonic foraminifera (many of them adults) being found; they are normally very rare and usually small juveniles and it is not surprising that they have been almost totally neglected. With a resurgence of interest in the marine Neogene and Quaternary of the British Isles and in the light of a detailed taxonomic study of the Ostracoda of the St. Erth Beds being undertaken at present by Whatley \& Maybury (University College of Wales, Aberystwyth), it would seem opportune to offer this more complete synthesis of the planktonic foraminifera based on all the material to hand (Collections of Millett, Heron-Allen and Earland, and Whatley). In this paper, 15 species are discussed and illustrated; it is not only the first time that planktonic foraminifera have been illustrated from the St. Erth Beds, but also the first time from the Neogene of mainland Britain, as far as we are aware.

All figured specimens are housed in the Protozoa Section, Department of Palaeontology, British Museum (Natural History), London, registered nos. P 51672 - P 51692.

The systematic treatment is brief, confining itself to the original citation, redescriptions of type material and significant papers where the generic names used in the present text were first used or adequately explained. 


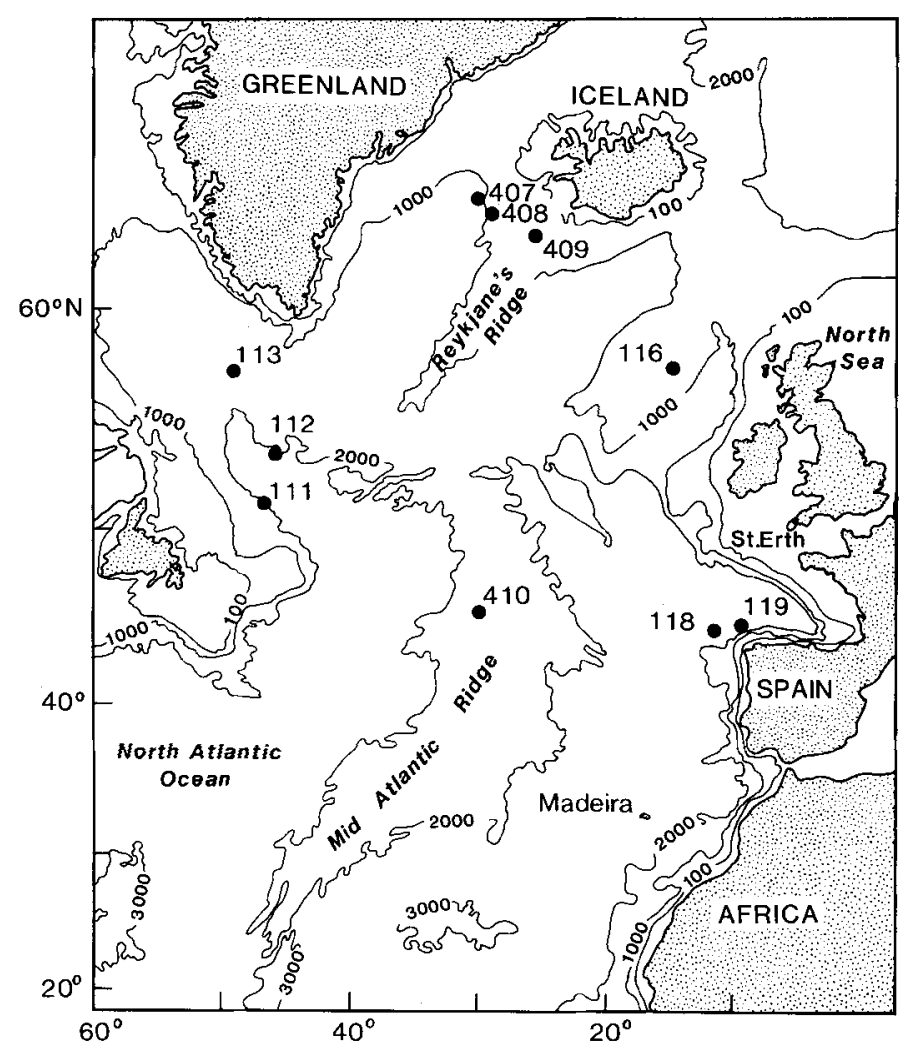

Fig. 1. Map of North Atlantic showing location of selected D.S.D.P. sites and St. Erth; water depths in metres.

\section{THE ST. ERTH PLANKTONIC FORAMINIFERA}

\section{Globigerina bradyi Wiesner}

(Pl. 1, fig. 7)

1884 Globigerina sp. Brady: 603, pl. 82, figs. 8, 9. 1931 Globigerina bradyi Wiesner: 133.

1960 Globigerina bradyi Wiesner; Banner \& Blow: 5, pl. 3, figs. 1, 2 (lectotype).

Remarks. There is some disagreement in the literature as to whether $G$. bradyi is in fact synonymous with $G$. uvula (Ehrneberg) (= Pylodexia uvula Ehrenberg, 1861 ) as the original figures of the latter are ambiguous. We follow Blow (1969) and Bé (1977) in regarding $G$. bradyi as a distinct species.

Stratigraphic range. Bolli (1957) recorded G. bradyi in Trinidad from the Early Miocene Globorotalia kugleri Zone to the Late Miocene G. menardii Zone. Its range in New Zealand was recorded as Early Oligocene $G$. angiporoides Zone to the Pleistocene $G$. inflata Zone by Jenkins $(1966,1967)$. Blow (1969) recorded the species from Early Miocene (Zone N4) to Recent and both Brady (1884) and Wiesner (1931) found it living today.
Palaeogeographic range. G. bradyi appears to have evolved in the southern hemisphere in the Early Oligocene and then spread throughout the world oceans. Bé (1977) gives its present day distribution as the Arctic to Subarctic and Antarctic to Subantarctic faunal provinces.

\section{Globigerina bulloides d'Orbigny}

(PI. 1, figs. 1-3)

1791 "Polym. Tuberosa et Globulifera" Soldani (pars): 117, pl. 123, figure 0 only (Vas 251).

1826 Globigerina bulloides d'Orbigny: 227, list No. 1, modèle No. 76 only.

1960 Globigerina bulloides d'Orbigny; Banner \& Blow: 3, pl. 1. figs. 1a-c (lectotype).

Stratigraphic range. Blow (1969) recorded $G$. bulloides s. $s$. (as G. bulloides bulloides) as having a range from Late Miocene (Zone N16) to Recent, but Jenkins $(1966,1967)$ included Blow's $G$. praebulloides and $G$. parabulloides within the concept of d'Orbigny's species and recorded its New Zealand range as far back as the Oligocene $G$. angiporoides Zone. 
Palaeogeographic range. $G$. bulloides is found in modern oceans from the Arctic and Antarctic to their respective Transition faunal provinces (Bé 1977). Since the Oligocene at least, the $G$. bulloides group has been most abundant in the higher and mid-latitudes.

Globigerina cf. G. cariacoensis Rögl \& Bolli (Pl. 1, fig. 4)

cf. 1973 Globigerina megastoma Earland cariacoensis Rögl \& Bolli: 564, pl. 2, figs. 1-10; pl. 11, figs. 7,10 ; pl. 12 , figs. 5, 6; text-figs. 4a-c.

Remarks. This small, high spired form is only tentatively placed in Rögl \& Bolli's taxon. Their holotype is much larger with a diameter of $0.40 \mathrm{~mm}$ as compared with the largest of the St. Erth specimens (that figured) which is only $0.23 \mathrm{~mm}$ in diameter. G. cariacoensis is considered by Kennett \& Srinivasan (1983) to be merely a variant of $G$. bulloides d'Orbigny.

Stratigraphic range. Known only from the Pleistocene and Holocene. It was originally described from D.S.D.P. site 147 in the Caribbean (Late PleistoceneHolocene). Poore (1978) recorded it from the Late Pleistocene of sites 407, 409 and 410 in the North Atlantic (see our Fig. 1), while Poore \& Berggren (1975) defined the base of the Pleistocene in the Hatton-Rockall Basin on the first appearance of this species.

\section{Globigerina falconensis Blow (Pl. 1, figs. 5, 6)}

1959 Globigerina falconensis Blow: 177, pl. 9, figs. $40,41$.

Stratigraphic range. Blow (1959) originally described the species from the Miocene-Pliocene of Venezuela; in 1969 he gave its total range as Early Miocene (Zone N7) to Recent. Jenkins \& Orr (1972) recorded its range in the Equatorial Pacific region as mid-Miocene (Globorotalia peripheroacuta/ $G$. fohsi fohsi Zone) to the present day.

Palaeogeographic range. A clue as to its past areal distribution is to be found in the modern oceans where Bé (1977) regarded its presence in the Subtropical province as an extension of its close relative $G$. bulloides from higher and mid-latitudes. In New Zealand it is present in relatively low numbers from the Early Miocene to Early Pliocene where its local extinction is regarded as being due to a deterioration in climatic conditions.
Globigerina juvenilis Bolli

(Pl. 1, figs. 9, 10)

1957 Globigerina juvenilis Bolli: 110, pl. 24, figs. 5a-6.

Remarks. G. juvenilis has been suggested by many authors to be merely Globigerinita glutinata (Egger) without the umbilical bulla and Bé (1977) did not recognise it as a separate species in the modern oceans. It is here recognised because in some areas $G$. juvenilis occurs without $G$. glutinata, and this could be due to some palaeoenvironmental factor.

Stratigraphic range. Bolli (1957) recorded its range in Trinidad from the Early Miocene Globorotalia kugleri Zone to the mid-Miocene $G$. menardii Zone. Its Austral range was established by Jenkins $(1966,1967)$ in New Zealand from the mid-Oligocene Globigerina angiporoides Zone into the Pleistocene Globorotalia inflata Zone. Blow (1969) recorded it from the base of Zone N4 (early Miocene) to Recent.

\section{Globigerinita glutinata (Egger) \\ (Pl. 1, fig. 8)}

1893 Globigerina glutinata Egger: 371, pl. 13, figs. 19-21.

1962 Globigerinita glutinata (Egger); Parker: 246, pl. 9, figs. 1-16.

Remarks. For comments on the wide range of variation in the development of the umbilical bulla and the different names the resultant forms have been given, see Kennett \& Srinivasan (1983).

Stratigraphic range. In New Zealand it appeared later in the Oligocene than Globigerina juvenilis (see above) and ranges through to the Pleistocene (Jenkins, 1971). Kennett \& Srinivasan (1983) give its range as Late Oligocene (Zone P22) to Recent.

Palaeogeographic range. In the present oceans $G$. glutinata has been found from the Subarctic and Subantarctic provinces to the Tropical belt, with the greatest numbers in the Subtropical province (Bé 1977).

\section{Globigerinoides triloba (Reuss) \\ (Pl. 2, figs. 6, 9)}

1849 Globigerina triloba Reuss: 10, pl. 2, figs. 11a-e. 1850 Globigerina triloba Reuss: 374, pl. 47, figs. 11 a-e.

1965 Globigerinoides quadrilobatus (d'Orbigny) trilobus (Reuss) (sic); Banner \& Blow: 105, pl. 16, fig. 4 . 
Remarks. Some authors (e.g. Banner \& Blow, 1965) would regard $G$. triloba as a subspecies of $G$. quadrilobatus, a name which has priority (d'Orbigny, 1846). We prefer to retain specific status for $G$. triloba, while at the same time regarding $G$. immaturus LeRoy (1939) as synonymous. Bé (1977) includes both $G$. triloba and $G$. immaturus in $G$. sacculifer (Brady), even though Brady's taxon (erected 1877) would clearly be a junior synonym. The St. Erth material includes an adult specimen.

Stratigraphic range. Bolli (1957) recorded the range of $G$. triloba in Trinidad from the Early Miocene Catapsydrax dissimilis Zone to the Late Miocene Globorotalia menardii Zone. In New Zealand, Jenkins (1966, 1967) gives its range from the Early Miocene Globigerinoides trilobus (sic) Zone to the Pleistocene Globorotalia inflata Zone. Parker (1962) found it in the Recent of the Pacific and Blow (1969) gives its total range of Early Miocene to Recent.

Palaeogeographic range. Bé (1977) states that in the modern oceans it occurs from the Subartic and Subantarctic to Subtropical provinces with greatest numbers in the Transitional faunal provinces.

\section{Globorotalia inflata (d'Orbigny)}

(Pl. 2, figs. 4, 5)

1839 Globigerina inflata d'Orbigny: 134, pl. 2, figs. 7-9.

1967 Globorotalia (Turborotalia) inflata (d'Orbigny); Banner \& Blow: 144, pl. 4, figs. 1a-c (neotype), 11.

Remarks. The Millet Collection yielded an adult specimen (figs. herein); juveniles occurred in all our material from St. Erth.

Stratigraphic range: In the North Atlantic the first appearance of $G$. inflata was recorded by Poore \& Berggren (1975) as within the early part of Zone N21 (Late Pliocene); this marks the base of their Globorotalia inflata Zone (see our Fig. 2). Weaver \& Clement (1985, in press) have now shown that this species first appears in the N. Atlantic at $2.1 \mathrm{Ma}$. In the New Zealand region (Jenkins, 1971) and South Atlantic (Jenkins, 1978), it has been recorded from the Late Pliocene to Recent.

Palaeogeographic range. Bé (1977) states that in the modern oceans it occurs from the Subartic and Subantarctic to Subtropical provinces, with the greatest numbers in the Transitional faunal provinces.

\section{Globorotalia praehirsuta Blow}

(PI. 1, figs. 19-21)

1969 Globorotalia (Globorotalia) hirsuta praehirsuta Blow (sic): 400, pl. 43, figs. 3-7.
Stratigraphic range. Although Blow (1969) originally recorded its range from the Late Miocene (Zone N18) to the Pleistocene (Zone N22), and stated that it gave rise to the true $G$. hirsuta (d'Orbigny), the extinction of G. praehirsuta within the Late Pliocene of the North Atlantic appears to be a good marker. At D.S.D.P. site 112 , in the Labrador Sea, Poore \& Berggren (1974) record it with some frequency in the Early Pliocene but soon afterwards it disappears, while at sites 410 and $410 \mathrm{~A}$ (see Fig. 1) it ranges only from Late Miocene to Late Pliocene (within the $G$. inflata Zone) (Poore, 1978).

Palaeogeographic range. $G$. praehirsuta was not recorded by Poore \& Berggren (1975) from site 116 at lat. $57^{\circ} 30^{\prime} \mathrm{N}$ (see Fig. 1) or by Poore (1978) at the still more northern sites 408 and 409 . Its northern palaeogeographic limit, therefore, seems to have been between St. Erth (lat. $51^{\circ} \mathrm{N}$ ) and site 116 .

$$
\begin{gathered}
\text { Globorotalia scitula (Brady) } \\
\text { (Pl. 1, figs. 15, 16) }
\end{gathered}
$$

1882 Pulvinulina scitula Brady: 716.

1960 Pulvinulina scitula Brady; Banner \& Blow: 27, pl. 5, figs. 5a-c (lectotype).

1969 Globorotalia (Turborotalia) scitula scitula (Brady); Blow: 356, pl. 39, fig. 7.

Remarks. The few small specimens from St. Erth have $4 \frac{1}{2}-5$ chambers in the final whorl, strongly recurved sutures on the spiral side and are dextrally coiled. On the umbilical side of the illustrated specimen (P1. 1, fig. 16) pustules are developed on the first few chambers, a feature previously recorded in this species by Jenkins \& Orr (1972, pl. 31, figs. 4, 5).

Stratigraphic range. Bolli (1957), Blow (1969) and Jenkins (1971) are in agreement concerning the first appearance of $G$. scitula near the base of the Middle Miocene; it occurs today in modern oceans.

Palaeogeographic range. Bé (1977) gives its present day occurrence as the Subarctic and Subantarctic provinces with few specimens in the Transition zone.

\section{Globorotalia tosaensis Takayanagi \& Saito} (Pl. 2, figs. 1-3)

1962 Globorotalia tosaensis Takayanagi \& Saito: 81, pl. 28 , figs. 11,12 .

Remarks. G. tosaensis is distinguished from its descendant $G$. truncatulinoides (d'Orbigny) in having a rounded outline when viewed from the umbilical/ 


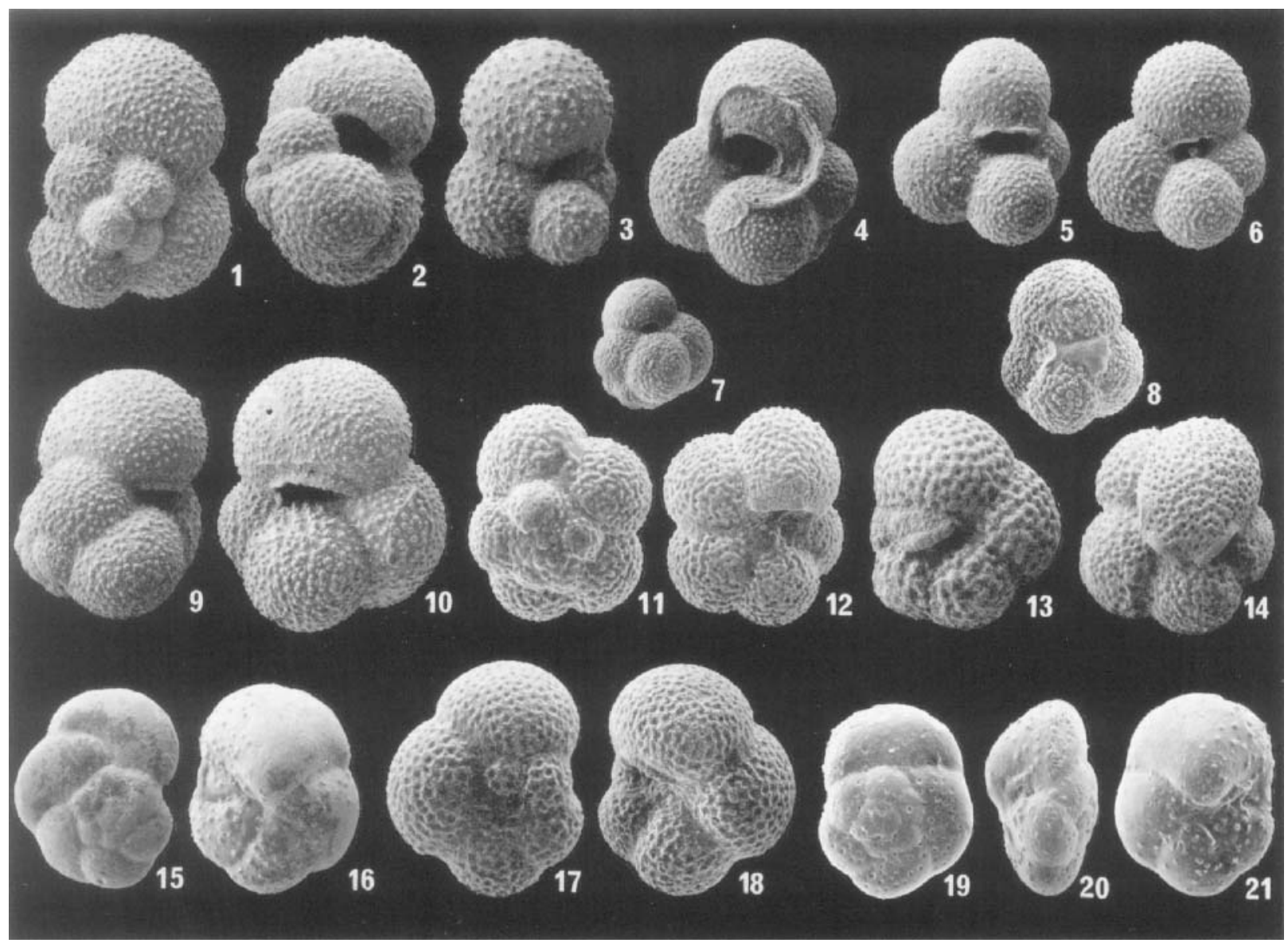

\section{Explanation of Plate 1}

All figures are $\times 130$

Figs. 1-3. Globigerina bulloides d'Orbigny. Spiral, edge and umbilical views of three specimens, P 51672 - P 51674, respectively. Whatley Collection.

Fig. 4. Globigerina cf. cariacoensis Rögl \& Bolli. Umbilical view, P 51675. Whatley Collection.

Figs. 5, 6. Globigerina falconensis Blow. Spiral views of two specimens, P 51676 and P 51677, respectively. Whatley Collection.

Fig. 7. Globigerina bradyi Wiesner. Umbilical view, P 51678. Whatley Collection.

Fig. 8. Globigerinita glutinata (Egger). Umbilical view, P 51679. Earland Collection (P 37929), ex Millett.

Figs. 9, 10. Globigerina juvenilis Bolli. Edge and umbilical views of two specimens, P 51680 and P 51681, respectively. Whatley Collection.

Figs. 11, 12. Neogloboquadrina humerosa (Takayanagi \& Saito). Spiral and umbilical views, P 51682. Whatley Collection.

Figs. 13, 17, 18. Neogloboquadrina pachyderma (Ehrenberg): fig. 13, umbilical view of "bullate" form, P 51683, Whatley Collection; figs. 17, 18, spiral and umbilical views, P 51687, Earland Collection (P 37929), ex Millett.

Fig. 14. Turborotalita quinqueloba (Natland). Umbilical view, P 51684. Whatley Collection.

Figs. 15, 16. Globorotalia scitula (Brady). Spiral and umbilical views of two specimens, P 51685 and P 51686, respectively. Whatley Collection.

Figs. 19-21. Globorotalia praehirsuta Blow. Spiral, edge and umbilical views, P 51688. Earland Collection (P 37929), ex Millett. 
spiral side and in not possessing a keel. A single adult specimen and several juveniles were found in the Millett Collection.

Stratigraphic range. Parker (1967) recorded it in Indo-Pacific cores from the Late Pliocene to Early Pleistocene, and Blow (1969) gives its range worldwide from Zone $\mathrm{N} 21$ to within $\mathrm{N} 22$, an almost identical timespan. The latest extinction is given by Saito et al. (1981) at just above the Brunhes/Matuyama boundary (c. $0.7 \mathrm{Ma}$ ). In the North Atlantic its first appearance is within the $G$. inflata Zone but its extinction is harder to pinpoint: at D.S.D.P. site 111 Poore \& Berggren (1974) recorded it from the Early Pleistocene, but without G. truncatulinoides, while Poore (1978), at site 410 (see Fig. 1), has it dying out within the Early Pleistocene at c. $1.5 \mathrm{Ma}$.

Palaeogeographic range. The extant G. truncatulinoides, the immediate descendant of $G$. tosaensis, ranges from the Subarctic and Subantarctic to Subtropical provinces with only a few specimens found in the Tropical belt. In the North Atlantic Late Pliocene, $G$. tosaensis is found from latitudes $45^{\circ}$ to $54^{\circ} \mathrm{N}$ (Table 1); St. Erth lies at approximately $51^{\circ} \mathrm{N}$.

Neogloboquadrina humerosa (Takayanagi \& Saito) (Pl. 1, figs. 11, 12)

1962 Globorotalia humerosa Takayanagi \& Saito: 78, pl. 78 , figs. $1,2$.

1976 Neogloboquadrina humerosa (Takayanagi \& Saito); Srinivasan \& Kennett: 335, pl. 6, figs. 1-13.

Remarks. Only small right coiling specimens are present in the St. Erth Beds. They lack the apertural lip of $N$. acostaensis (Blow).

Stratigraphic range. There is agreement that $N$. humerosa evolved from $N$. acostaensis in the Late Miocene, but some disagreement exists as to the date of its extinction. Blow (1969) gives its range as extending into the Recent, while Srinivasan \& Kennett (1976), in their detailed work on the $N$. dutertrei plexus, have its extinction within the Late Pliocene, only later extending the upper range into the Early Pleistocene in the S.W. Pacific (Kennett \& Srinivasan, 1983).

Palaeogeographic range. $N$. humerosa has a wide distribution in the North Atlantic from D.S.D.P. sites 407 and 408 in the north $\left(63^{\circ} \mathrm{N}\right)$ to 410 in the south $\left(45^{\circ} \mathrm{N}\right)$ but elsewhere it appears to have had a preference for sub-tropical to warm tropical waters (Kennett \& Srinivasan, 1983). It is therefore concluded that its more northern distribution in the North Atlantic was due to the Gulf Stream.

\section{Neogloboquadrina pachyderma (Ehrenberg)}

(Pl. 1, figs. 13, 17, 18)

1861 Aristerospira pachyderma Ehrenberg: 303.

1873 Aristerospira pachyderma Ehrenberg; Ehrenberg: pl. 1, fig. 4.

1962 Globigerina pachyderma (Ehrenberg); Parker: 224 , pl. 1, figs. 26-35, pl. 2, figs. 1-6.

1983 Neogloboquadrina pachyderma (Ehrenberg); Kennett \& Srinivasan: 192, pl. 47, figs. 2, 6-8.

Remarks. The taxonomic problems surrounding the identity of Ehrenberg's original description and figure are discussed by Parker (1962); Kennett \& Srinivasan (1983) adequately review the generic assignment of this species. Numerous dextrally coiled specimens are found in the St. Erth samples, as already reported by Jenkins (1982), some having the bulla-like final chamber as illustrated in $\mathrm{Pl}$. 1, fig. 13.

Stratigraphic range. Jenkins (1967) recorded the range of $N$. pachyderma in New Zealand from the Late Miocene to Recent and this has been confirmed by later workers, including Poore (1978), from the North Atlantic. Poore and Berggren (1975) recorded a significant change of coiling from dextral in the Late Pliocene to sinistral in the Early Pleistocene at D.S.D.P. site 116 (see Figs. 1, 2), west of Scotland. Palaeogeographic range. $N$. pachyderma appears to

\section{Explanation of Plate 2}

All figures are $\times 130$

Figs. 1-3. Globorotalia tosaensis Takayanagi \& Saito. Spiral, edge and umbilical views, P 51689. From slide labelled Pulvinulina crassa d'Orbigny. Heron-Allen \& Earland Collection, ex Millett.

Figs. 4, 5. Globorotalia inflata (d'Orbigny). Spiral and umbilical views, P 51690. Heron-Allen \& Earland Collection, ex Millett.

Figs. 6, 9. Globigerinoides triloba (Reuss). Spiral and umbilical views, P 51691. Heron-Allen \& Earland Collection, ex Millett.

Figs. 7, 8. Pulleniatina primalis Banner \& Blow. Edge and umbilical views, P 51692. From slide labelled Pullenia obliquiloculata Parker \& Jones. Heron-Allen \& Earland Collection, ex Millett. 


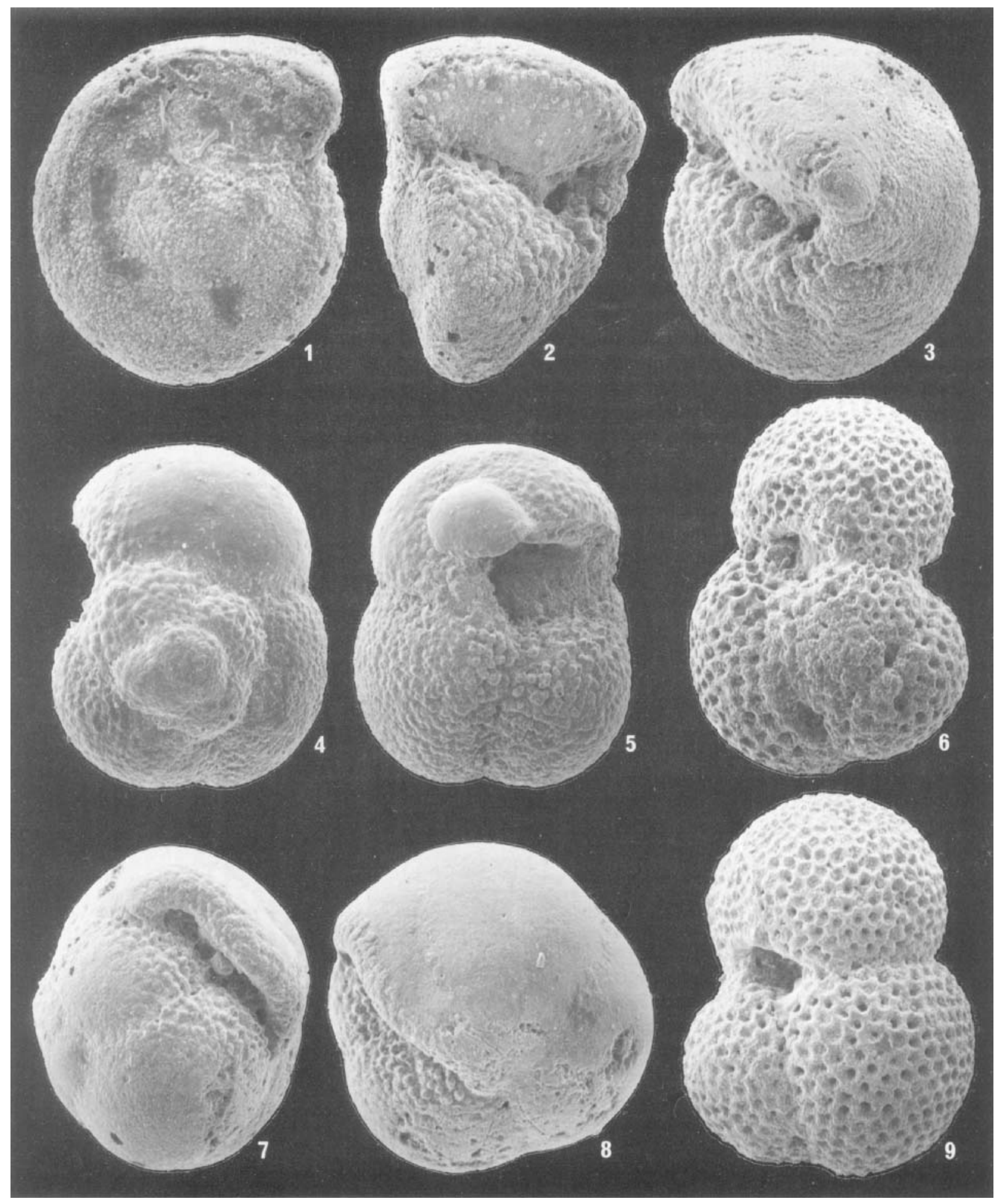


Table 1. Records of species in the Late Pliocene of various D.S.D.P. sites in the North Atlantic, Poore \& Berggren (1975), Poore (1978); St. Erth represents only a small time interval in the late Pliocene. Tropical species are marked with a "T" at sites 410 and 119 (see Fig. 1).

$$
\mathrm{N} \leftarrow
$$

$\frac{\text { DSDP Site }}{\text { Latitude }}$

Species North

$407+408$

116

113

112

St. Erth

111

118

119

410

\section{Globigerina}

G. bradyi

G. bulloides

G. calida

G. cf. cariacoensis

63

57

56

54

51

50

45

45

45

G. decoraperta

G. eamesi

G. falconensis

$G$. foliata

G. juvenilis

G. praedigitata

G. uvula

G. umbilicata

$G$. cf. venezuelana

G. woodi

Globigerinella

G. aequilateralis

Globigerinita

G. glutinata

Globigerinoides

$G$. conglobatus

$G$. extremus

$G$. obliquus

G. quadrilobatus

G. ruber

G. rubescens

G. sacculifer

G. triloba

Globoquadrina

G. altispira

Globorotalia

$G$. bermudezi

$G$. crassaformis

G. crassula

$G$. hirsuta

$G$. inflata

G. Limbata

G. praehirsuta

G. puncticulata

$G$. scitula

$G$. tosaensis

Hastigerina

H. pelagica

Neogloboquadrina

$N$. acostaensis

$N$. atlantica

$N$. dutertrei

N. humerosa

N. pachyderma

Orbulina

$O$. universa

Pulleniatina

$P$. primalis

Sphaeroidinella

S. dehiscens

Turborotalita

T. quinqueloba

$\begin{array}{ll}\mathrm{x} & \mathrm{x} \\ \mathrm{x} & \mathrm{x} \\ \mathrm{x} & \mathrm{x} \\ \mathrm{x} & \mathrm{x} \\ \mathrm{x} & \mathrm{x} \\ \mathrm{x} & \mathrm{x} \\ \mathrm{x} & \\ \mathrm{x} & \\ & \end{array}$

$\mathrm{x}$

$\mathrm{x}$

$\mathrm{X}$

$\mathrm{x}$

$\mathrm{x}$

$\mathrm{x}$

$\mathrm{x}$

$\mathrm{x}$

$\mathrm{x}$

$\mathrm{x}$

$\mathrm{x}$

$\mathrm{x}$

$\mathrm{x}$

$\mathrm{x}$

T $\quad x$

$\mathrm{x}$

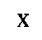

$\mathrm{x}$

$\mathrm{x}$

x T $\quad \mathrm{x} \mathrm{T}$

$\mathrm{x}$

x T

x T

$x$ ?

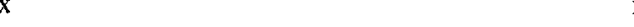

$\mathrm{x} \mathrm{T}$

$\mathrm{x}$

$\mathrm{x}$

$\mathrm{x}$

$\mathrm{x}$

$\mathrm{x}$

$\mathbf{x}$

$\mathrm{x} T$

$\mathrm{x}$

$\mathrm{x}$

$\mathrm{x}$

$x$

$x$ cf.

$\mathrm{x}$

x T

$\mathrm{x}$

$\mathrm{x}$

$\mathrm{x}$

$\mathrm{x}$

$\mathrm{x}$

$\mathrm{x}$

$$
\mathrm{x}
$$

$\mathrm{x}$

x

$\mathrm{x}$

$\mathrm{x}$

x T

$x$

$\begin{array}{lll} & & \mathrm{x} \mathrm{T} \\ & & \\ & & \mathrm{x} \\ \mathrm{x} & & \mathrm{x} \\ \mathrm{x} & & \mathrm{x} \\ & & \mathrm{x} \\ & & \mathrm{x}\end{array}$

$\mathrm{x}$

x T

$\mathrm{x}$

$\mathrm{x}$

$\mathrm{x}$

$\mathrm{x}$ 
have had a more wide-spread range in the Late Miocene and Pliocene, and only became restricted mainly to the mid-high latitudes in the Pleistocene. According to Kennett \& Srinivasan (1983), dextrally coiled specimens are dominant in the temperate regions of the modern oceans and sinistrally coiled populations in the cooler regions.

\section{Pulleniatina primalis Banner \& Blow}

$$
\text { (Pl. 2, figs. 7, 8) }
$$

1967 Pulleniatina primalis Banner \& Blow: 142, pl. 1, figs. 3-8, pl. 3, figs. 2a-c.

Remarks. The illustrated specimen from the Millett Collection is a mature individual with a diameter of $0.39 \mathrm{~mm}$; it shows all the main characteristics of the species (see Banner \& Blow, 1967, p. 137).

Stratigraphic range. The range of $P$. primalis, particularly the extinction, is somewhat controversial. Parker (1967) gave the range in Indo-Pacific cores as Late Miocene to Late Pliocene, while Blow (1969) recorded it from mid Zone N17 (Late Miocene) to within Zone N20 (Early Pliocene). Kennett \& Srinivasan (1983) give an almost identical range to Blow's. Keigwin (1982) stated that in the Atlantic, $P$. primalis first appeared at only 4.2 Ma (Zone N19) as compared with c. $5.5 \mathrm{Ma}$ (Zone N17) in the Pacific, also that it disappeared at 3.3 Ma (Zone N19/20) in the former area only to reappear again at $2.1 \mathrm{Ma}$ (Zone $\mathrm{N} 21$ ) in the Late Pliocene. Parker (1973) recorded $P$. primalis from the Late Pliocene of the tropical North Atlantic at D.S.D.P. site 29 (lat. $14^{\circ} \mathrm{N}$ ). Contrary to Saito et al.'s (1981) claims for records into the Pleistocene, we consider it to have become extinct within the Late Pliocene, and that supposed younger specimens are probably immature $P$. obliquiloculata (Parker \& Jones).

Palaeogeographic range. There is no record of $P$. primalis at any of the North Atlantic D.S.D.P. sites (Table 1) but at site 410 its descendant species $P$. obliquiloculata is present in the Pleistocene. Kennet \& Srinivasan (1983) regard $P$. primalis as a tropical to warm subtropical species and there is some oxygen isotope evidence that it lived in the surface waters (Keller, 1985); this would help to explain its presence in the shallow water St. Erth beds.

\section{Turborotalita quinqueloba (Natland)}

$$
\text { (Pl. 1, fig. 14) }
$$

1938 Globigerina quinqueloba Natland: 149, pl. 6, fig. 7.

1984 Turborotalita quinqueloba (Natland); Holmes: 101 et seq., pl. 3, figs. 9-11.
Remarks. This species is placed in Turborotalita following the revision of that genus by Holmes (1984), the apertural position and presence of ampulla being the significant criteria.

Stratigraphic range. Both Jenkins (1966, 1967) and Kennett \& Srinivasan (1983) give its first appearance as Early Miocene; however, Blow (1969) places this as late as Zone N17 (late Miocene). The species is living today.

Palaeogeographic range. Poore (1978) recorded $T$. quinqueloba from the Middle Miocene to Pleistocene at D.S.D.P. sites 407,408 and 410 in the North Atlantic (between $45^{\circ}$ and $63^{\circ} \mathrm{N}$ ).

\section{AGE AND CORRELATION}

The age-diagnostic species in the St. Erth fauna are Globorotalia inflata, G. tosaensis, G. praehirsuta, Pulleniatina primalis, Neogloboquadrina humerosa and dextral N. pachyderma, their ranges overlapping near the top of the Late Pliocene (Fig. 2).

The evolution of $G$. inflata from $G$. puncticulata (Deshayes) is well documented in the southeast Pacific (Malmgren \& Kennett, 1981) and the descendant species was used to mark the base of both the $G$. inflata Zone and the Late Pliocene in the North Atlantic (Poore \& Berggren, 1975). More recent work has shown that $G$. inflata first appeared in the North Atlantic at 2.1 Ma (Weaver \& Clement, 1985 in press), and it ranges through to the Recent. Similarly, the evolution of $G$. tosaensis from $G$. crassaformis (Galloway $\&$ Wissler) is well documented in the Late Pliocene (Srinivasan \& Kennett, 1981).

According to Blow (1969), G. praehirsuta ranges from the Early to Late Pliocene. N. pachyderma, on the other hand, ranges from the Late Miocene to Recent, but in the North Atlantic the Pliocene populations are dextral with a change to sinistral in the Early Pleistocene (Berggren, 1972); the St. Erth material is entirely dextrally coiled. $N$. humerosa ranges from the middle Miocene to Late Pliocene in the North Atlantic (Poore, 1978).

$P$. primalis also ranges through from the Late Miocene but it became extinct in the Late Pliocene (Parker, 1967); a few authors have extended its range into the Pleistocene (Saito et al., 1981) but it is contended here that these records are misidentification of juveniles of $P$. obliquiloculata (Parker \& Jones).

It is also of some importance to note the absence of the following age-diagnostic species from the St. Erth fauna: Globorotalia puncticulata (Deshayes), G. truncatulinoides (D' Orbigny) and Neogloboquadrina atlantica (Berggren) (Fig. 2). G. puncticulata ranges up to 2.3 Ma in the North Atlantic according to Weaver \& Clement (1985 in press) (Fig. 2). Poore (1978) records the evolutionary transition from $G$. tosaensis to $G$. truncatulinoidies at the Pliocene-Pleistocene boundary 


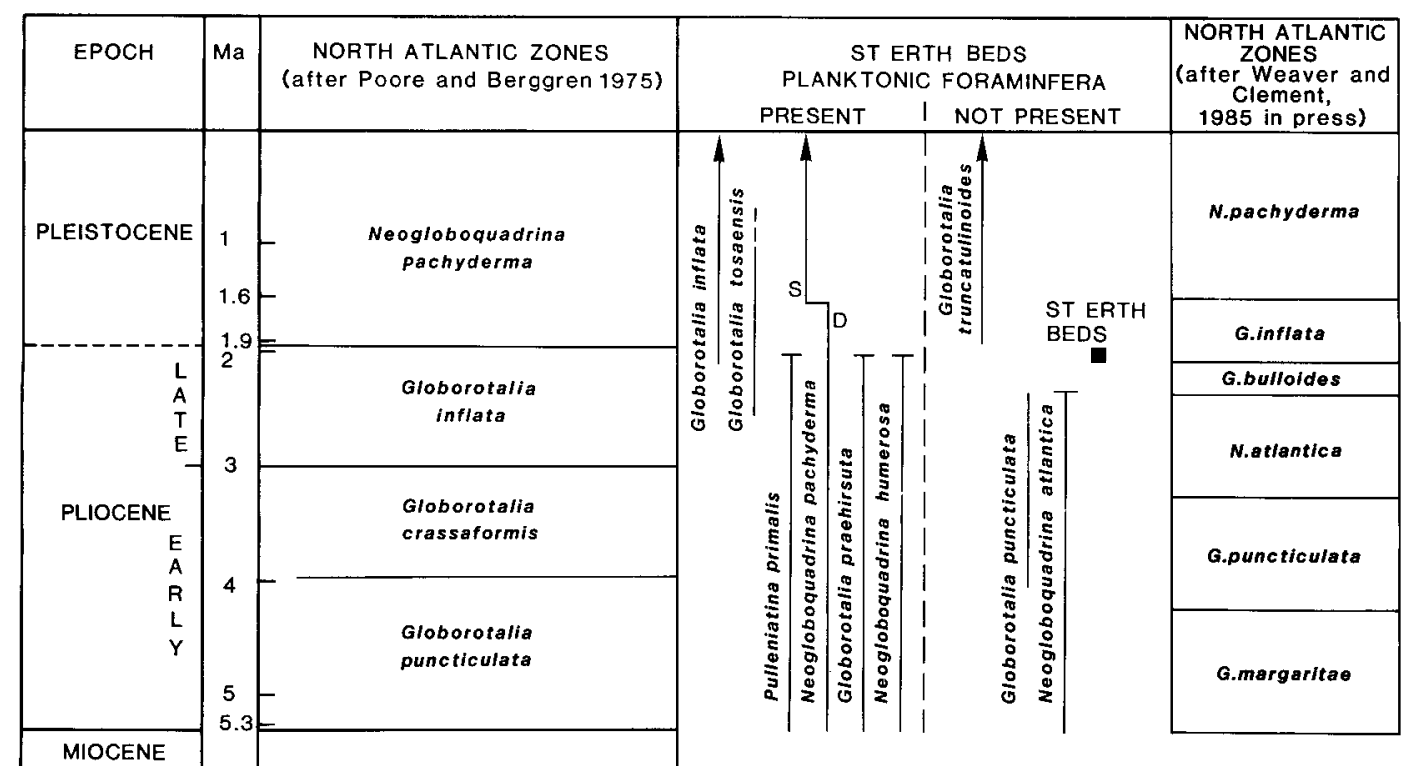

Fig. 2. The stratigraphic position of the St. Erth Beds based on ranges of key species of planktonic foraminifera plotted against Poore \& Berggren's (1975) and Weaver \& Clement's (in press) zonations, and the Plio-Pleistocene time-scale (Berggren et al., 1985).

which took place at about $1.9 \mathrm{Ma} . N$. atlantica, in the northern North Atlantic, ranges from the late Miocene to the top of the Pliocene in the D.S.D.P. sites 407,408 and 116 but in the more southern D.S.D.P. site 410 (Poore, 1978) and in the Mediterranean it became extinct earlier in the lower part of the Late Pliocene (Fig. 3). The latitudinal position of St. Erth has been plotted on to Fig. 3 and it can be seen that the absence of $N$. atlantica can be explained because of the diachronous nature of its extinction. Also, there is additional evidence by Weaver \& Clement (1985 in press) that $N$. atlantica became extinct at $2.3 \mathrm{Ma}$ between latitudes $49^{\circ}$ and $53^{\circ}$ north in the northeastern Atlantic.

The marine clays at St. Erth have a rich and very diverse microfauna. Although there is evidence (Catt \& Weir, in Mitchell et al., 1973) that the apparently unfossiliferous St. Erth sands which underly the clays

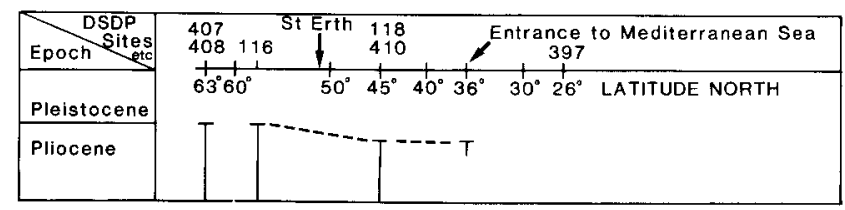

Fig. 3. Stratigraphic ranges of Neogloboquadrina atlantica (Berggren) in the North Atlantic illustrating the diachronous nature of its extinction; its short range in the Mediterranean was recorded by Sparak, 1981. were redeposited, it is unlikely that the clays themselves are reworked. Indeed, from the preservation and known distribution of the planktonic foraminifera it has to be assumed that they are all contemporaneous. According to Mitchell et al., (1973; 33-34) . . . "some changes in conditions, perhaps a further rise in sea level, initiated the deposition of highly fossiliferous clay" and deposition took place ... "in a relatively short time". From both the positive and negative evidence outlined above, it can be seen that this statement can now be verified and that the deposition took place within the Late Pliocene, between c. 2.1 and 1.9 Ma ago (Fig. 2).

It will be interesting to see whether planktonic foraminifera can now be found in the Redonian deposits of N.W. France which Margarel (in Mitchell et al., 1973) correlated with St. Erth on benthic foraminiferal evidence. The Coralline Crag of East Anglia, which as recently as 1981 (Hughes \& Jenkins, 1981) was also considered to be the approximate chronostratigraphical equivalent of the St. Erth Beds but has been dated as Early Pliocene by King (1983). An analysis of the planktonic foraminifera of the Coralline Crag is being undertaken (Jenkins et al., in press).

\section{PLIO-PLEISTOCENE BOUNDARY}

The placement of the Plio-Pleistocene boundary has some relevance to the age of the St. Erth Beds. For a number of years it was placed at $1.85 \mathrm{Ma}$, marked by the first evolutionary appearance of $G$. truncatulinoides 
in the Atlantic (Berggren et al., 1967). More recently, the boundary has been variously put at ages ranging from c. 1.9 to $1.6 \mathrm{Ma}$. The most recent work of Berggren et al. (1985) prefers to place the boundary at $1.6 \mathrm{Ma}$, approximately coincident with the top of the Olduvai Event but $0.3 \mathrm{Ma}$ after the first appearance of G. truncatulinoides. This is, for the most part, based on the work of Colalongo et al., 1981, on the Vrica Section in Southern Italy. Unfortunately, the boundary at Vrica is determined by the First Appearance Datum of the first of the so-called "cold" or "northern guests", the ostracod Cytheropteron testudo Sars, but Whatley (pers. comm. and written evidence to the INQUA Sub-commission on the Plio-Pleistocene Boundary) has now shown it to be neither the true $C$. testudo nor a "cold guest". We therefore prefer to retain the boundary (Fig. 2) at c. $1.9 \mathrm{Ma}$, approximately at the first appearance of $G$. truncatulinoides.

\section{PALAEOGEOGRAPHY}

Pomerol (1982) stated that the St. Erth Beds . . . "contribute nothing to the problem of the opening of the eastern end of the English Channel". In the light of our new evidence, do the planktonic foraminifera throw any light as to whether the Channel was open in the Late Pliocene?

Of the St. Erth species, only $G$. inflata and $N$. pachyderma were recorded by King (1983) from the Late Pliocene of the North Sea. This is an exceptionally low diversity when compared with similar aged deposits of the N.E. Atlantic and St. Erth (Table 1). It points to a North Sea with a restricted circulation, blocked off to the south by a closed English Channel and joined northwards to the cooler waters of the N.E. Atlantic.

\section{PALAEOECOLOGY}

From a study of the St. Erth species of planktonic foraminifera which are still living today, Jenkins (1982) postulated that the palacotemperature of the relatively shallow water at the time of the deposition of the clays was in the range of $10-18^{\circ} \mathrm{C}$. The presence of $G$. falconensis suggested that it was towards the upper end of the temperature range and this is now supported by the presence of $G$. tosaensis and $P$. primalis, whose modern descendants, $G$. truncatulinoides and $P$. obliquiloculata respectively, occur in subtropical water.

Cifelli \& Glacon (1979) were of the opinion that the western margin of the North Atlantic Gyre was about $10^{\circ}$ latitude further north in the Early Pliocene as compared with its present position, with its eastern margin . . . "diffuse, as it is today". The Late Pliocene St. Erth faunas continue to reflect this more northern position of the North Atlantic Gyre.

\section{CONCLUSIONS}

The relatively rare planktonic foraminifera of the highly fossiliferous marine clay at St. Erth give a Late Pliocene age determination. The temperature of the relatively shallow water must have been towards the upper part of the range $10-18^{\circ} \mathrm{C}$.

Manuscript received February 1985

Revised manuscript accepted July 1985

\section{REFERENCES}

Banner, F. T. \& Blow, W. H. 1960. Some primary types of species belonging to the superfamily Globigerinacea. Contr. Cushman Fdn. foramin. Res., 11, 1-41, pls. 1-8.

Banner, F. T. \& Blow, W. H. 1965. Globigerinoides quadrilobatus (d'Orbigny) and related forms; their taxonomy, nomenclature and stratigraphy. Contr. Cushman Fdn. foramin. Res., 16, 105-115, pl. 16.

Banner, F. T. \& Blow, W. H. 1967. The origin, evolution and taxonomy of the foraminiferal genus Pulleniatina Cushman, 1927. Micropaleontology, 13, 133-162, pls. 1-4.

Bé A. W. H. 1977. An ecological, zoogeographic and taxonomic review of Recent planktonic foraminifera. In Ramsay, A. T. S. (Ed), Oceanic Micropalaeontology, 1, 1-100, pls. 1-12. Academic Press, London.

Berggren, W. A., Phillips, J. D., Bertels, A. \& Wall, D. 1967. Late Pliocene-Pleistocene stratigraphy in deep-sea cores from the south central North Atlantic. Nature, 216, 253-254.

Berggren, W. A. 1972. Cenozoic biostratigraphy and paleobiogeography of the North Atlantic. Init. Repts. Deep Sea Drilling Project, 12, 965-999, pls. 1-13.

Berggren, W. A., Kent, D. V. \& van Couvering, J. A. 1985. The Neogene: Part 2, Neogene geochronology and chronostratigraphy. In Snelling, N. (Ed.), Chronology and the Geological record. Geol. Soc. Lond. Mem no. 10, 211-260.

Blow, W. H. 1959. Age, correlation and biostratigraphy of the upper Tocuyo (San Lorenzo) and Pozón formations, eastern Falcon, Venezuela. Bull. Am. Paleont., 39, 67-251, pls. 6-19.

Blow, W. H. 1969. Late middle Eocene to Recent planktonic foraminiferal biostratigraphy. In Brönnimann, P. \& Renz, H. H. (Eds), Proceedings of First International Conference on Planktonic Microfossils, Geneva 1967, 1, 199-422, pls. 1-54. Brill, Leiden.

Bolli, H. M. 1957. Planktonic foraminifera from the Oligocene-Miocene Cipero and Lengua formations of Trinidad, B.W.I. Bull. U.S. Natn. Mus., 215, 97-123, pls. 22-29.

Brady, H, B. 1877. Supplementary note on the Foraminifera of the Chalk (?) of the New Britain group. Geol. Mag., 4, 534-536.

Brady, H. B. 1882. Report on the Foraminifera. Proc. $R$. Soc. Edinb., 11, 708-717.

Brady, H. B. 1884. Report on the Foraminifera dredged by H.M.S. Challenger, during the years 1873-1876. Rep. Scient. Results. Voy. Challenger (Zool)., 9, 1-814, pls. 1-115.

Catt, J. A. \& Weir, A. H. 1973. The sediments. In Mitchell, G. F. et al. The Late Pliocene marine formation at St Erth, Cornwall. Phil. Trans. R. Soc. ser. B., 266, 12-18, fig. 13.

Cifelli, R. \& Glacon, G., 1979. New Late Miocene and Pliocene occurrences of Globorotalia species from the North Atlantic; and a paleogeographic review. J. foramin. Res., 9(3), 210-227. 
Colalongo, M. L., Pasini, G. \& Sartoni, S. 1981. Remarks on the Neogene/Quaternary boundary and the Vrica Section (Calabria, Italy). Boll. Soc. Paleont. Ital., 20, 99-120, pls. 1-3.

Egger, J. G. 1893. Foraminiferen aus Meeresgrundproben, gelonthet von 1874 bis 1876 von S.M. Sch. Gazelle. $A b h$. bayer. Akad. Wiss., 18(2), 1-166 (193-458), pls. 1-21.

Ehrenberg, C. G. 1861. Elemente des tiefen Meeresgrundes im Mexikanischen Golfstrome bei Florida; über die Tiefgrund-Verhältnisse des Oceans am Eingange der Davisstrasse und bei Island. Mber. K. preuss. Akad. Wiss., 1861, 275-315.

Ehrenberg, C. G. 1873. Mikrogeologische Studien über das kleinste Leben der Meeres-Tiefgründe aller Zonen und dessen geologischen Einfluss. Phys. Math. Abh. K. Akad. Wiss. Berlin, 1872, 131-397, pls. 1-12.

Holmes, N. A. 1984. An emendation of the genera Beella Banner and Blow, 1960, and Turborotalita Blow and Banner, 1962, with notes on Orcadia Boltovskoy and Watanabe, 1982. J. foramin. Res., 14, 101-110, pls. 1-3.

Hughes, M. \& Jenkins, D. G. 1981. Neogene. In Jenkins, D. G. \& Murray, J. W. (Eds), Stratigraphic Atlas of Fossil Foraminifera, 268-285, pls. 9.1-9.3. Ellis Horwood, Chichester for British Micropalaeontological Society.

Jenkins, D. G. 1966. Planktonic foraminiferal zones and new taxa from the Danian to Lower Miocene of New Zealand. N.Z. Jl. Geol. Geophys., 8, 1088-1126.

Jenkins, D. G. 1967. Planktonic foraminiferal zones and new taxa from the Lower Miocene to Pleistocene of New Zealand. N.Z. Jl. Geol. Geophys., 10, 1064-1078.

Jenkins, D. G. 1971. New Zealand Cenozoic planktonic foraminifera. Palaeont. Bull. N.Z. Geol. Surv., 42, 1-278, pls. 1-23.

Jenkins, D. G. 1978. Neogene planktonic foraminifera from D.S.D.P. Leg 40, sites 360 and 362 in the southeastern Atlantic. Int. Repts. Deep Sea Drilling Project, 40, 723-739, pls. 1-3.

Jenkins, D. G. 1982. The age and palaeoecology of the St. Erth Beds, southern England, based on planktonic foraminifera. Geol. Mag., 119, 201-205.

Jenkins, D. G., Curry, D., Funnell, B. J. \& Whittaker, M. E. In press. Planktonic foraminifera from the Early Pliocene Coralline Crag of East Anglia, England.

Jenkins, D. G. \& Orr, W. N. 1972. Planktonic foraminiferal biostratigraphy of the eastern equatorial Pacific - D.S.D.P. Leg 9. Init. Repts. Deep Sea Drilling Project, 9, 1060-1193, pls. 1-41.

Keigwin, L. D. 1982. Neogene planktonic foraminifera from Deep Sea Drilling Project sites 502 and 503. Init. Repts. Deep Sea Drilling Project, 68, 269-288, pls. 1-11.

Keller, G. 1985. Depth stratification of planktonic foraminifers in the Miocene Oceans. In Kennett, J. P. (Ed), The Miocene Ocean, Geol. Soc. Amer. Memoir 163, 177-195.

Kennett, J. P. \& Srinivasan, M. S. 1983. Neogene planktonic foraminifera, a phylogenetic atlas. 265 pp; 61 pls. Hutchinson Ross Publ. Comp., Stroudsburg.

King, C. 1983. Cainozoic micropalaeontological biostratigraphy of the North Sea. Rep. Inst. Geol. Sci., 82/7, 1-40, pls. $1-6$.

Le Roy, L. W. 1939. Some small Foraminifera, Ostracoda and otoliths from the Neogene ("Miocene") of the RokanTapanoeli area, central Sumatra. Natuurk. Tijdschr. Med.Indië, 99, 215-296, pls. 1-14.
Malmgren, B. A. \& Kennett, J. P. 1981. Phyletic gradualism in a Late Cenozoic planktonic foraminiferal lineage; D.S.D.P. Site 284, southwest Pacific. Paleobiology, 7, 230-240.

Margarel, J. P. 1973. The Foraminifera. In Mitchell, G. F. et al., The Late Pliocene marine formation at St Erth, Cornwall. Phil. Trans. R. Soc. ser. B, 266, 25-29, figs. 14-16.

Millett, F. W. 1885. Notes on the fossil foraminifera of the St. Erth clay pits. Trans. R. Geol. Soc. Corn., 10(7), 213-216.

Millett, F. W. 1886. Additional notes on the foraminifera of the St. Erth Clay. Trans. R. Geol. Soc. Corn., 10(8), 222-226.

Millett, F. W. 1895. The foraminifera of the Pliocene Beds of St. Erth. Trans. R. Geol. Soc. Corn., 11(9), 655-661, pl. 1.

Millett, F. W. 1898. Additions to the list of foraminifera from the St. Erth Clay. R. Geol. Soc. Corn., 12(3), 174-176, pl. 1.

Mitchell, G. F. (with contributions by Catt, J. A., Weir, A. H., McMillan, N. F., Margarel, J. P. \& Whatley, R. C.). 1973. The Late Pliocene marine formation at St Erth, Cornwall. Phil. Trans. R. Soc. ser, B, 266, 1-37, figs. 1-16.

Natland, M. L. 1938. New species of foraminifera from off the west coast of North America and from the later Tertiary of the Los Angeles Basin. Bull. Scripps. Instn. Oceanogr. Tech. Ser., 4, 137-152, pls. 3-7.

Orbigny, A. D. d' 1826. Tableau méthodique de la classe des Cephalopodes. Annls Sci. nat. ser. 1, 7, 96-169, 245-314, pls. 10-17.

Orbigny, A. D. d' 1839. Foraminifères des Iles Canaries. In Barker-Webb, P. \& Berthelot, S. Histoire naturelle des Iles Canaries (Zool), 2(2), 121-146, pls. 1-3. Paris.

Orbigny, A. D. d' 1846. Foraminifères fossiles du Bassin Tertiaire de Vienne (Autriche). $312 \mathrm{pp}, 21 \mathrm{pls}$. Gide et Comp., Paris.

Parker, F. L. 1962. Planktonic foraminiferal species in Pacific sediments. Micropaleontology, 8, 219-254, pls. 1-10.

Parker, F. L. 1967. Late Tertiary biostratigraphy (planktonic foraminifera) of tropical Indo-Pacific deep-sea cores. Bull. Am. Paleont., 52, 115-208, pls. 17-32.

Parker, F. L. 1973. Late Cenozoic biostratigraphy (planktonic foraminifera) of tropical Atlantic deep-sea sections. Revta. Esp. Micropaleont., 5(2), 253-289.

Pomerol, C. 1982. The Cenozoic Era. Tertiary and Quaternary. 272 pp. Ellis Horwood, Chichester.

Poore, R. Z. 1978. Oligocene through Quaternary planktonic foraminiferal biostratigraphy of the North Atlantic: D.S.D.P. Leg 49. Init. Repts. Deep Sea Drilling Project, 49, 447-517, pls. $1-20$.

Poore, R. Z. \& Berggren, W. A. 1974. Pliocene biostratigraphy of the Labrador Sea: calcareous plankton. $J$. foramin. Res., 4, 91-108, pls. 1-3.

Poore, R. Z. \& Berggren, W. A. 1975. Late Cenozoic planktonic foraminiferal biostratigraphy and paleoclimatology of Hatton-Rockall Basin, D.S.D.P. Site 116. J. foramin. Res., 5, 270-293, pls. 1-5.

Poore, R. Z. 1978. Oligocene through Quaternary planktonic foraminiferal biostratigraphy of the North Atlantic: DSDP Leg 49. Init. Repts. Deep Sea Drilling Project, 49, 447-517, pls. 1-20.

Reuss, A. E. 1849, 1850. Neue Foraminiferen aus den Schichten des Osterrichischen Teriärbeckens. 26 pp, 6 pls. Vienna (1849). (Same title) Denkschr. Akad. Wiss. Wien, 1, 365-390, pls. 46-51. (1850). 
Rögl, F. \& Bolli, H. M. 1973. Holocene to Pleistocene planktonic foraminifera of Leg 15, Site 147 (Cariaco Basin (Trench) Caribbean Sea) and their climatic interpretation. Init. Repts. Deep Sea Drilling Project, 15, 553-615, pls. $1-18$.

Saito, T., Thompson, P. R. \& Breger, D. 1981. Systematic index of Recent and Pleistocene planktonic foraminifera. 190 pp, 56 pls. Univ. of Tokyo Press.

Soldani, A. 1791. Testaceographiae ac Zoophytographiae parvae et microscopiae., 1(2), 87-200, pls. 94-142. Senis (Sienna).

Spaak, P. 1981. The distribution of the Globorotalia inflata group in the Mediterranean Pliocene. Proc. K. ned. Akad. Wet., ser. B, 84, 210-215, pls. 1, 2.

Srinivasan, M. S. \& Kennett, J. P. 1976. Evolution and phenotypic variation in the Late Cenozoic Neogloboquadrina dutertrei plexus. In Takayanagi, Y. \& Saito, T. (Eds.), Progress in Micropaleontology. Micropaleontology Spec. Publ., 2, 329-355, pls. 1-8.

Srinivasan, M. S. \& Kennett, J. P. 1981. A review of Neogene planktonic foraminiferal biostratigraphy: applications in the equatorial and South Pacific. In Warme, J. E., Douglas, R. G. \& Winterer, E. L. (Eds.), The Deep Sea Drilling Project: A Decade of Progress. Spec. Publs. Soc. econ. Paleont. Miner., 32, 395-432.

Takayanagi, Y. \& Saito, T. 1962. Planktonic foraminifera from the Nabori Formation, Shikoku, Japan. Sci. Rep. Tohoku Univ, ser. 2 (Geol.), 5, 67-106, pls. 24-28.

Weaver, P. P. E. \& Clement, B. M. 1985. In press. Magnetobiostratigraphy of planktonic foraminiferal datums: D.S.D.P. Leg 94 North Atlantic. Init. Repts. Deep Sea Drilling Project, 94.

Whitley, N. 1882. The evidence of glacial action in Cornwall and Devon. Trans. R. Soc. Corn. 10, 132-141.

Wiesner, H. 1931. Die Foraminiferen. Dt. Sudpol--Exped., 20, 53-165, pls. 1-24. 